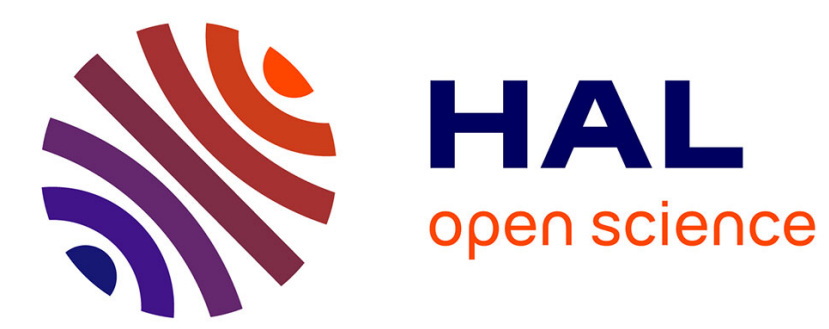

\title{
The Development of Double-Oriented Silicon Steel with Cube Orientation
}

\author{
A. Sakakura
}

\section{To cite this version:}

A. Sakakura. The Development of Double-Oriented Silicon Steel with Cube Orientation. Journal de Physique IV Proceedings, 1995, 05 (C7), pp.C7-219-C7-224. 10.1051/jp4:1995724 . jpa-00254017

\section{HAL Id: jpa-00254017 https://hal.science/jpa-00254017}

Submitted on 1 Jan 1995

HAL is a multi-disciplinary open access archive for the deposit and dissemination of scientific research documents, whether they are published or not. The documents may come from teaching and research institutions in France or abroad, or from public or private research centers.
L'archive ouverte pluridisciplinaire HAL, est destinée au dépôt et à la diffusion de documents scientifiques de niveau recherche, publiés ou non, émanant des établissements d'enseignement et de recherche français ou étrangers, des laboratoires publics ou privés. 


\title{
The Development of Double-Oriented Silicon Steel with Cube Orientation
}

\author{
A. Sakakura
}

Nisshin Steel Co., Ltd., Koya-Shinmachi 7-1, Ichikawa City 272, Japan

\begin{abstract}
Silicon steels with cube orientation were extensively studied in the 1950s and 1960s, primarily for the purpose of using them as core materials for generators and large motors. In this paper, the research and development history of double-oriented silicon steel is outlined, as are the original attempts to subject hot bands containing AlN precipitates to cross-rolling treatment. It was found that the hot bands developed a (001) plane oriented secondary recrystallization structure after cross rolling and annealing, and that the percentage of grains with either (001)[100] or (001)[110]-orientations varied in accordance with the contents of carbon and AIN contained in hot band. Finally, some related fundamental research is discussed.
\end{abstract}

\section{INTRODUCTION}

This paper focuses on the process for producing silicon steel having a (001) plane in the rolling plane of the sheet. A grain-oriented silicon steel with (011)[100]-orientation is widely used as core material for transformers and turbo-generators, as shown in Fig.1(a). Of course, it would be preferable to use a doubleoriented silicon steel with (001)[100] or (001)[110]-orientations in large-sized stator (Figs.1(a) \&(b)). Moreover, though a non-oriented silicon steel has been used as core material for large-sized motors (Fig.1(c)), it would be more valuable to use a (001) plane oriented silicon steel in these motors. The object of this paper is to explain the process for producing a double-oriented and (001) plane oriented silicon steel, and to clarify the metallurgical mechanism by fundamental experiments using AlN containing $3 \% \mathrm{Si}-\mathrm{Fe}$ single crystals.

Double-oriented silicon steels with cube orientation were extensively studied in the 1950 s and1960s. J.L. Walter and co-workers [1 3] disclosed the multiple stage cold-rolling process of an oriented ingot for

producing a $3 \% \mathrm{Si}-\mathrm{Fe}$ with cube texture. $\mathrm{F}$. Assmuss and co-workers [4 5] invented the original multi-stage coldrolling process for treating a $3 \% \mathrm{Si}-\mathrm{Fe}$. This process was characterized by the final annealing in purified atmosphere. The (001)[100] cube oriented secondary recrystallization proceeds with the surface energy differentials acting as a driving force. H.H. Mobius[6 7] showed the two stage cold-rolling process for the production of a pronounced cube-orientation in a $2 \% \mathrm{Si}$ steel which was characterized by subjecting the coldrolled sheets to a predetermined ageing before final annealing. S. Taguchi and this author [7 11,13] disclosed a cross-rolling process for treating $3 \% \mathrm{Si}-\mathrm{Fe}$ containing a small amount of Al. The principle underlying this process is such that after the formation of a matrix by cross-rolling in which the cube grains are likely to grow, secondary recrystallization driven by grain boundary energy is initiated with impurity inhibition being effected by AIN. Furthermore, cubegrains containing $\operatorname{AlN}(S)$ so obtained could reproducethe same cube orientation after cold-rolling and

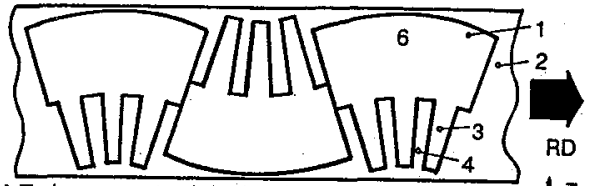

(a) Turbo-generator (single-, double-oriented) 47

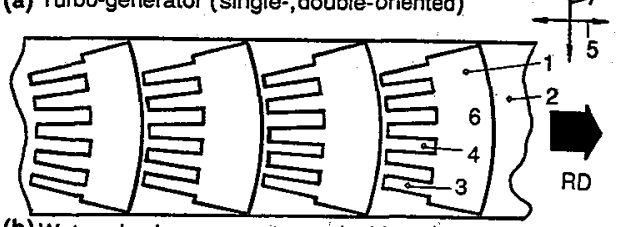

(b) Water wheel generator (non-,double- oriented)

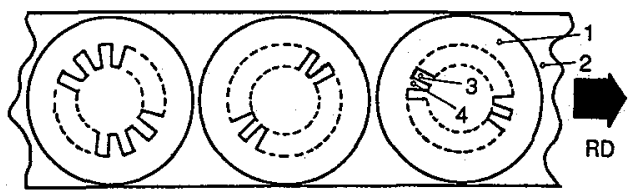

(c) Large motor (non- (001)-oriented)

Figure 1: Cores of large rotating machines 
Table 1 Magnetic properties of product developed by NSC[10]

$3 \%$ Si-Fe(Al) $\rightarrow$ Hot-roll $(3.0-\mathrm{mm}) \rightarrow$ Cross Cold-roll $(40 \times 40 \%, 1.1-\mathrm{mm}) \rightarrow$ Decarb. $\rightarrow$ Anneal $\left(1150^{\circ} \mathrm{C}, \mathrm{N} 50\right) \rightarrow$ Cube(AlN) $\rightarrow(S) \quad 3 C R(72 \%, 0.30-\mathrm{mm}) \rightarrow$ Final anneal $\left(1200^{\circ} \mathrm{C}, 20 \mathrm{~h}, \mathrm{NO0}\right)$...Secondary recrystallization(SC)

\begin{tabular}{|c|c|c|c|c|c|c|c|c|}
\hline $\begin{array}{l}\text { (S) } \\
\text { Structure }\end{array}$ & Direction & $\begin{array}{l}\text { B10 } \\
\text { (Gauss) }\end{array}$ & $\begin{array}{r}\text { Wis/50 } \\
(\mathrm{W} / \mathrm{kg}\end{array}$ & $\begin{array}{l}(\mathrm{P}) \\
\text { Structure }\end{array}$ & Direction & $\begin{array}{l}\text { B10 } \\
\text { (Gauss) }\end{array}$ & $\begin{array}{l}\text { W15/50 } \\
(\mathrm{W} / \mathrm{kg}\end{array}$ & Note of $r$ \\
\hline $\begin{array}{l}\text { Secondary } \\
\text { recrystn. }\end{array}$ & $\begin{array}{l}\mathrm{RD} \\
\mathrm{TD}\end{array}$ & $\begin{array}{l}19200 \\
19100\end{array}$ & $\begin{array}{l}1.01 \\
1.02\end{array}$ & $\begin{array}{l}\text { Primary } \\
\text { recrystn. }\end{array}$ & $\begin{array}{l}\mathrm{RD} \\
\mathrm{TD}\end{array}$ & $\begin{array}{l}16800 \\
16300\end{array}$ & $\begin{array}{l}1.50 \\
1.58\end{array}$ & $\begin{array}{l}\mathrm{B}_{10} ; \text { Induction at } 10 \text { Oersted } \\
\mathrm{W}_{15 / 50}: \text { Core loss at } 1.5 \mathrm{~T} \& 50 \mathrm{~Hz}\end{array}$ \\
\hline
\end{tabular}

\section{EXPERIMENTAL RESULTS}

\subsection{Experimental procedures for production of (001)-oriented samples}

Four different ingots 1,2,3 and 4 are processed by the methods as shown in Table 2 .

Table 2 Experimental procedure for preparation of samples Ingot $\rightarrow$ Slab-roll (Heat Temp.- $\left.{ }^{\circ} \mathrm{C}, \mathrm{RD}-\mathrm{LD}, \mathrm{T}-\mathrm{mm}\right) \rightarrow$ Hot-roll $\left(\right.$ Heat temp.- ${ }^{\circ} \mathrm{C}, \mathrm{RD}-\mathrm{TD}+\mathrm{LD}$ or LD, T-mm) $\rightarrow$ Anneal (Temp.- ${ }^{\circ} \mathrm{C}$, min., N2\%) $\rightarrow$ Cold-roll (Red.-\%,T-mm) $\rightarrow$ Decarb.anneal (Temp. ${ }^{\circ} \mathrm{C}$, min., N2-\%, wet) $\rightarrow$ OCA (Temp. $-{ }^{\circ} \mathrm{C}, \mathrm{hr}, \mathrm{N} 2-\%$, wet) $\rightarrow$ Final anneal (Temp. ${ }^{\circ} \mathrm{C}, \mathrm{hr}, \mathrm{N}_{2}-\%$, dry) $\rightarrow$ Measurement

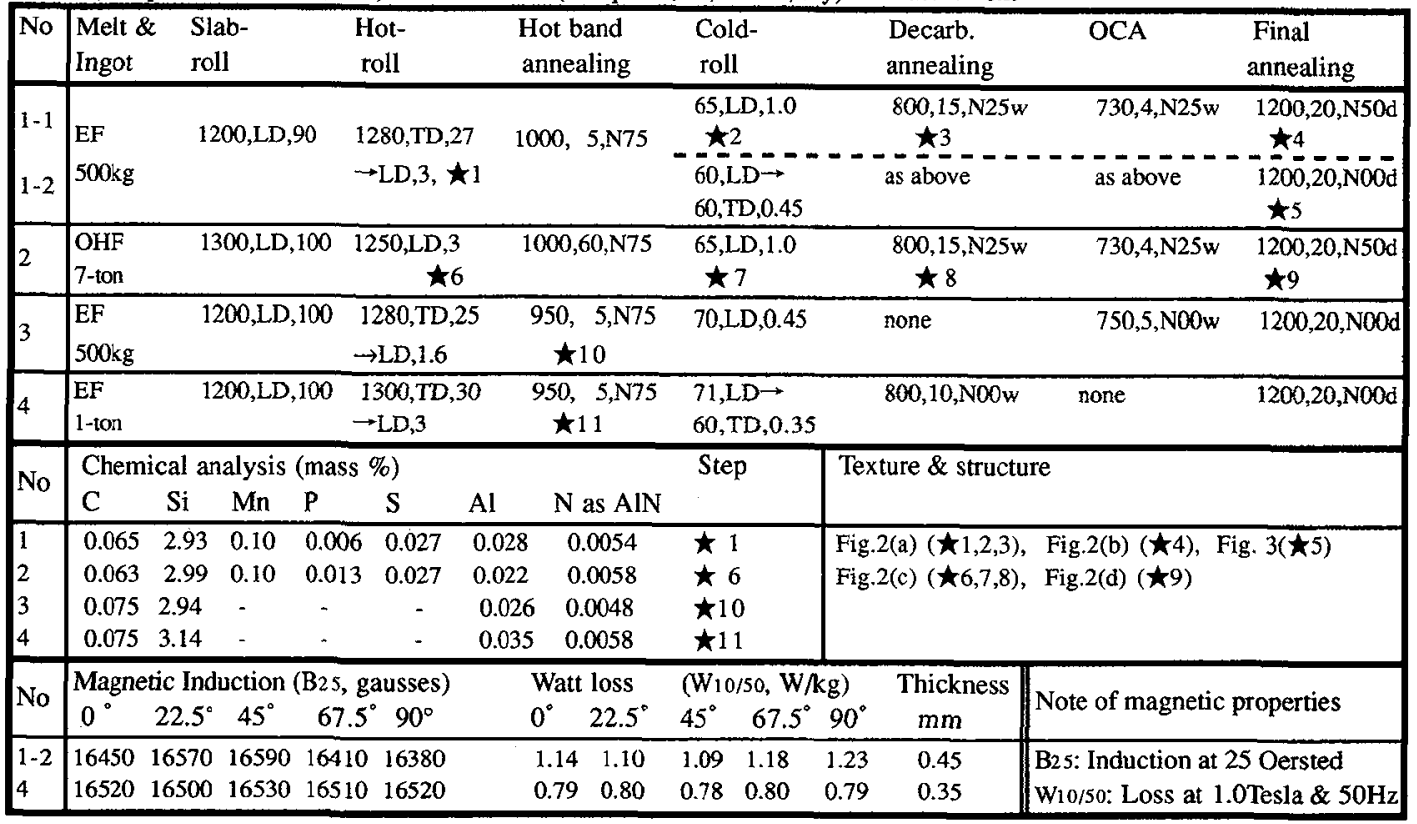

Note: RD-TD+LD (Rolling direction:Transverse direction+Longitudinal direction of ingot); T-mm(Thickness-mm) EF (Electric furnace); OHF (Open hearth furnace); OCA (Open coil annealing); Decarb.:Decarburizing annealing $\mathrm{N} 25 \mathrm{w}\left(\mathrm{N} 2,25 \%+\mathrm{H} 2,75 \%\right.$, wet atmosphere); Magnetic properties $\left(0,22.5,45,67.5\right.$ and $90^{\circ}$ to rolling direction)

\subsection{Experimental results and discussion}

As shown in Figs.2(a),(b),(c) and (d), (001)[100]-oriented secondaries are produced in the case of cross hot-rolling, while (011)[100]-oriented secondaries are produced in normal hot-rolling. Furthermore, in this cross hot-rolling process, the interesting fact has been found that even in carrying out the same cold-rolling and annealing processes, when more than $0.050 \% \mathrm{C}$ is contained in an ingot, (001)[110]-oriented secondaries such as $\mathrm{C} 7$ and $\mathrm{C} 8$ in sample 1-1 come to be mixed after final annealing in response to the carbon content of the ingot (Fig.2(b)). Furthermore in the case of sample 1-2 (cross cold-rolling, 0.45$\mathrm{mm}),(001)$ plane oriented silicon steel consisting of $45 \%$ of $(001)[100]$-oriented grains and $55 \%$ of (001)[110]-oriented grains respectively, is obtained (Fig.3). At any rate, the practical importance of this process for obtaining the $(001)$ plane oriented silicon steel resides in the combination of cross hot-rolling of 

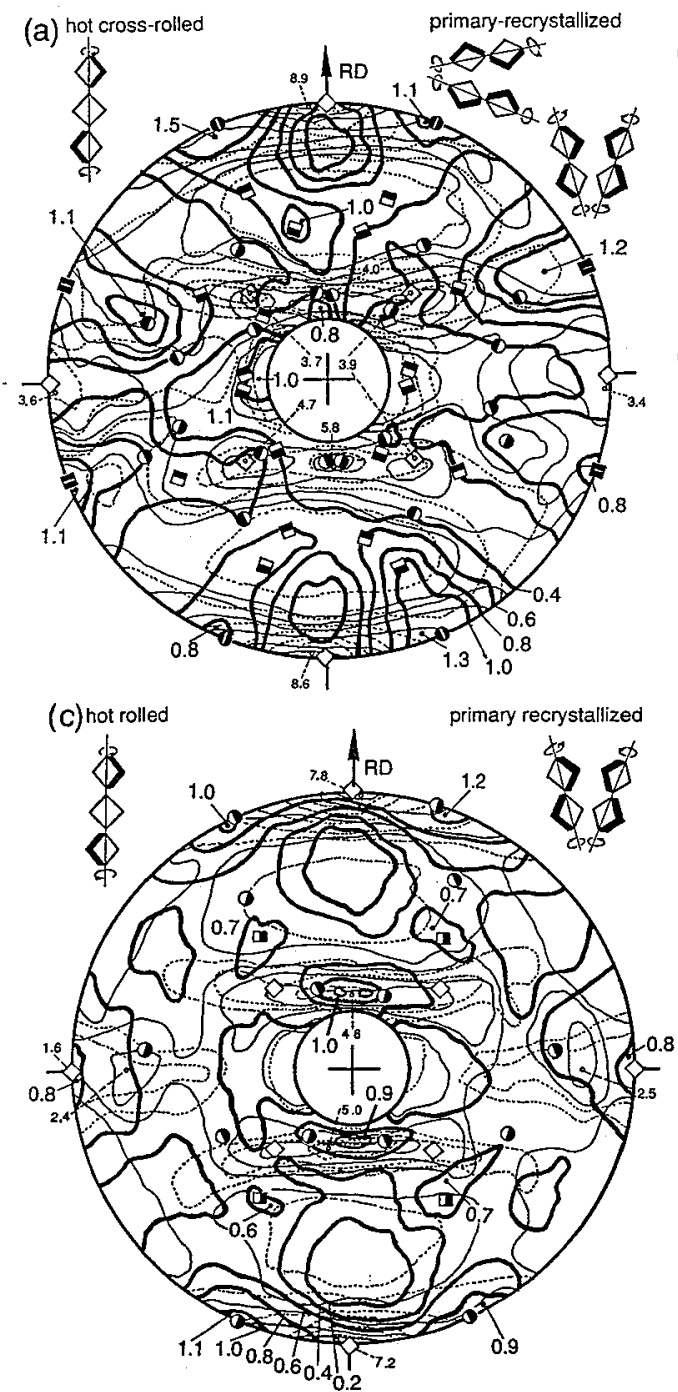

(b)
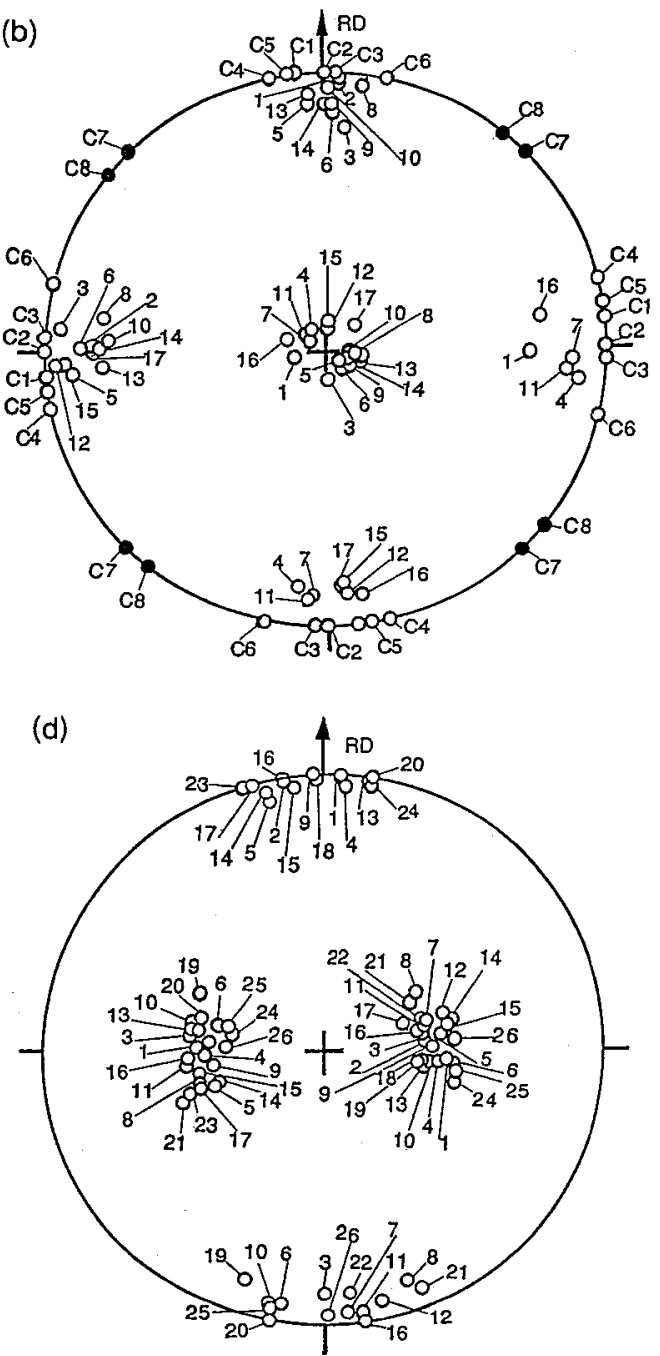

Figure 2: The texture change through processing of samples 1-1 and 2. 2(a) \& (c): (110) pole figures showing the orientations (Center of the thickness) of hot-rolled (cross-rolled 1-1 and normal-rolled 2,recrystallized $(-2(b) \&(d):(100)$ pole figures showing the orientations of secondaries of samples $1-1$ and 2 .

a slab containing small amounts of $\mathrm{Al} \& \mathrm{C}$ and cross cold-rolling. Figs. 4 and 5 show that the (001)[100] and (001)[110]-oriented secondaries are produced at percentages corresponding to the contents of $\mathrm{C} \sim \mathrm{Al}$ and C AlN in hot bands. Among these samples, the magnetic properties of samples $1-2(0.45-\mathrm{mm})$ and 4 $(0.35-\mathrm{mm})$ subjected to cross cold-rolling are shown in Table 2.

It is clear that these samples are (001) plane oriented, that is to say completely non-oriented silicon steel. From these figures, the following facts are obtained.

(1) $0.020 \sim 0.060 \%$ acid soluble $\mathrm{Al}$ and $0.030 \sim 0.080 \% \mathrm{C}$ are necessary for developing complete secondary recrystallization (Fig.4). It will be understood that $\mathrm{Al}$ is effective for formation of $\mathrm{AIN}$, and carbon is useful for keeping the (001)-plane structure in hot band.

(2) The combination of cross hot-rolling and cross cold-rolling processes are necessary for developing the (001)-oriented secondary recrystallization (Figs.3 \&4).

(3) The effect of hot-band annealing is great for secondary recrystallization because the necessary AlN precipitates will be formed in hot-band. 


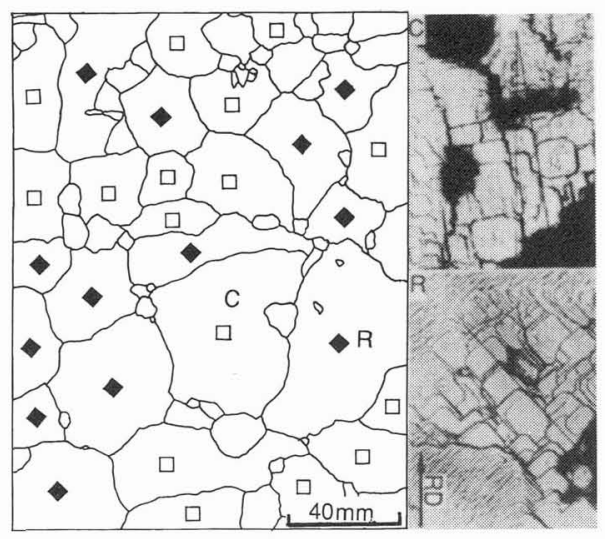

Figure 3:-Macrostructure showing secondaries of final annealed hot cross-rolled sample 1-2.

\section{FUNDAMENTAL EXPERIMENTS}

\subsection{Experimental procedure}

A study was made of the effects of AlN on recrystallization in cross-rolled and annealed (001)-oriented $3 \% \mathrm{Si}-\mathrm{Fe}$ single crystals to clarify the origination mechanism of (001) -oriented silicon steel. The single crystals used in this study were $3 \% \mathrm{Si}-\mathrm{Fe}$ with the $(001)$ plane in the rolling plane (Table 3). These were prepared by the author's method[11]. In the final annealing of this process, the sheets were kept for $20 \mathrm{hrs}$ at $1200^{\circ} \mathrm{C}$ and cooled at the rate of $100^{\circ} \mathrm{C} / \mathrm{h}$ in an $\mathrm{N} 50(\mathrm{~N} 250 \%+\mathrm{H} 250 \%)$ atmosphere. These crystals were then subjected to preheat treatments in order to change the size and distribution of AlN, and then cold rolled crosswise in the direction of $0^{\circ}$ and $45^{\circ}$ from the [100] direction, and finally annealed at $1200^{\circ} \mathrm{C}$. The processing conditions and the recrystallization structures and textures after final annealing are shown in Table 4.

\subsection{Experimental results and discussions}

Though the orientation of secondaries almost coincides with the initial crystal orientation (Fig.6), thereproducibility of the initial orientation is much more difficult in the case of (001)[110] (SR) than in the case of (001)[100] (SC)orientation. These (001)-oriented secondaries develop in crystals P00 and P45 which contain small amounts of AlN, precipitated as needles of about $1 \mu \mathrm{m}$ or less in length (Fig.7(b)).

Of course, in crystals N00 and N45 containing little or no AlN, normal grain growth structures PC and PR (Table 4) are formed. On the other hand, in (001)[110]-oriented crystal Q45 containing very fine AlN of about $0.01 \sim 0.1 \mu \mathrm{m}$ in length (Fig.7(a)), QR structure appears. This structure seems to be secondaries having four sets of a doublet $\{1,3,10\}<421>$-orientation (Fig.6) corresponding to the minor

Table 3 Chemical composition of starting crystals

\begin{tabular}{|c|c|c|c|c|c|c|c|c|c|}
\hline $\begin{array}{l}\text { Orientation of } \\
\text { starting crystals }\end{array}$ & $\begin{array}{l}\text { Methods of } \\
\text { preparation }\end{array}$ & $\begin{array}{l}\text { Chemical co } \\
\mathrm{Si} \quad \mathrm{Mn}\end{array}$ & $\begin{array}{c}\text { omposit } \\
\mathrm{Al}\end{array}$ & $\begin{array}{r}\text { tion }(\mathrm{ma} \\
\mathrm{C}\end{array}$ & ass \%) & $\mathrm{S}-\mathrm{N}$ & TN as Aly & $\begin{array}{l}\text { Thickness, } \\
\text { Diameter (mm) }\end{array}$ & Name of sample \\
\hline (001)-plane & Ref.11 & 2.950 .09 & 0.026 & 0.0040 & 0.0008 & 0.0150 & 0.0130 & $1.00,100 \phi$ & $\mathrm{P}, \mathrm{Q}, \mathrm{NO0} ; \mathrm{P}, \mathrm{Q}, \mathrm{N} 45$ \\
\hline
\end{tabular}


Table 4 Effects of AlN on the recrystallization textures in cold-rolled and annealed (001)-oriented crystals

\begin{tabular}{|c|c|c|c|c|c|c|c|c|c|c|}
\hline No & $\begin{array}{l}\text { Pre-heat trea } \\
\text { Temp. Time } \\
{ }^{\circ} \mathrm{C} \quad \text { Hr }\end{array}$ & $\begin{array}{l}\text { tment } \\
\text { Gas } \\
\mathrm{N}_{2}-\%\end{array}$ & Cool & $\begin{array}{l}\mathrm{N} \text { as } \\
\mathrm{AlN} \\
(\mathrm{ppm})\end{array}$ & $\begin{array}{l}\text { Reduction(\%) } \\
\quad \& \\
\text { Thickness }(\mathrm{mm})\end{array}$ & $\begin{array}{l}\text { Direction } \\
\text { of } \\
\text { rolling }\end{array}$ & $\begin{array}{l}\text { Final } \\
\text { Temp. } \\
{ }^{\circ} \mathrm{C}\end{array}$ & $\begin{array}{l}\text { nneal } \\
\text { Time } \\
\mathrm{Hr}\end{array}$ & $\begin{array}{l}\text { Gas } \\
\mathrm{N}_{2}-\%\end{array}$ & $\begin{array}{c}\text { Final structure \& } \\
\text { Orientation } \\
\text { (PGG: Primary grain growth) }\end{array}$ \\
\hline $\begin{array}{l}\text { P00 } \\
\text { P45 } \\
\text { Q00 } \\
\text { Q45 } \\
\text { NO0 } \\
\text { N45 }\end{array}$ & $\begin{array}{l}1350, \quad 5, \\
\text { as above } \\
1200,20, \\
\text { as above }\end{array}$ & $\begin{array}{l}\text { N75, } \\
\text { No0, }\end{array}$ & $\begin{array}{l}\text { WQ } \\
\text { Slow }\end{array}$ & $\begin{array}{c}130 \\
" \\
13 \\
" \\
4 \\
"\end{array}$ & $\begin{array}{l}\text { Cross rolling } \\
50 \times 50 \\
0.25\end{array}$ & $\begin{array}{l}{[100]} \\
{[110]} \\
{[100]} \\
{[110]} \\
{[100]} \\
{[110]}\end{array}$ & 1200 & 20 & N00 & $\begin{array}{l}\text { SC: }(001)[100]-\text { Secondary } \\
\text { SR: }(001)[110]-\text { Secondary } \\
\text { PC: }\{113\}<301>- \text { PGG } \\
\text { QR: }\{1,3,10\}<421>- \text { Secondary } \\
\text { PC: }\{113\}<301>- \text {-PGG } \\
\text { PR: }\left\{\begin{aligned} & \{13\}<110>,\{113\}<332> \\
& +\{1,3,10\}<421>\text { PGG }\end{aligned}\right.\end{array}$ \\
\hline
\end{tabular}
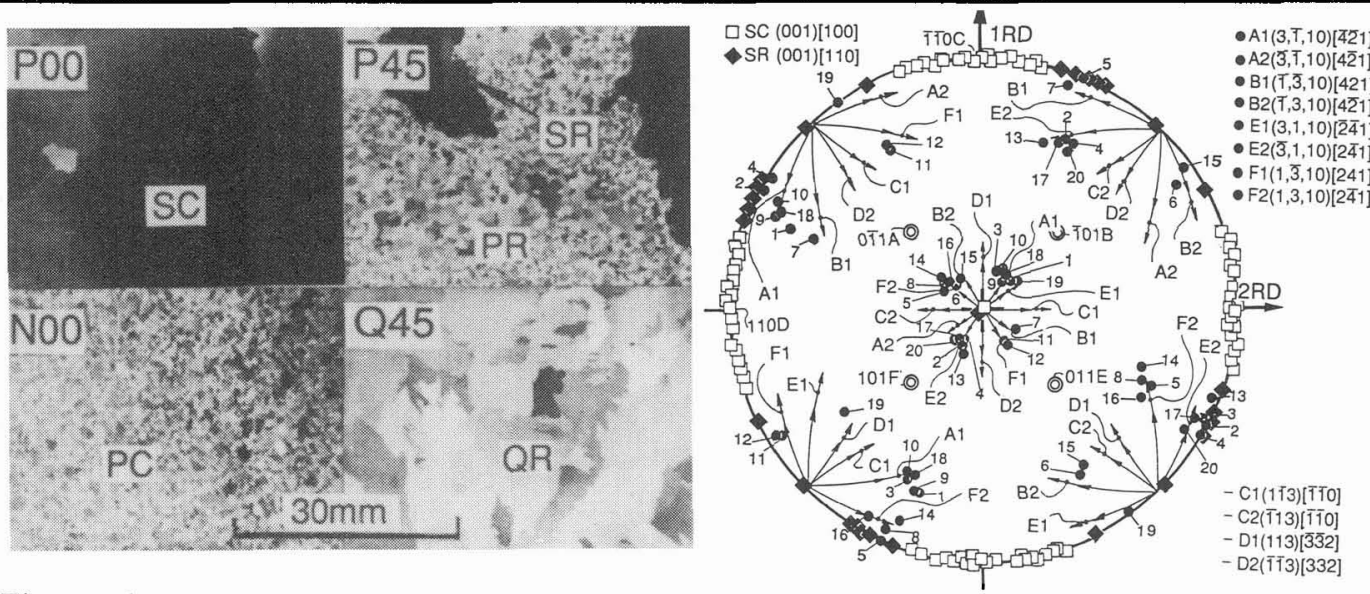

Figure 6-Macrostructure of the annealed crystals and (100) pole figure showing the orientation of secondaries.
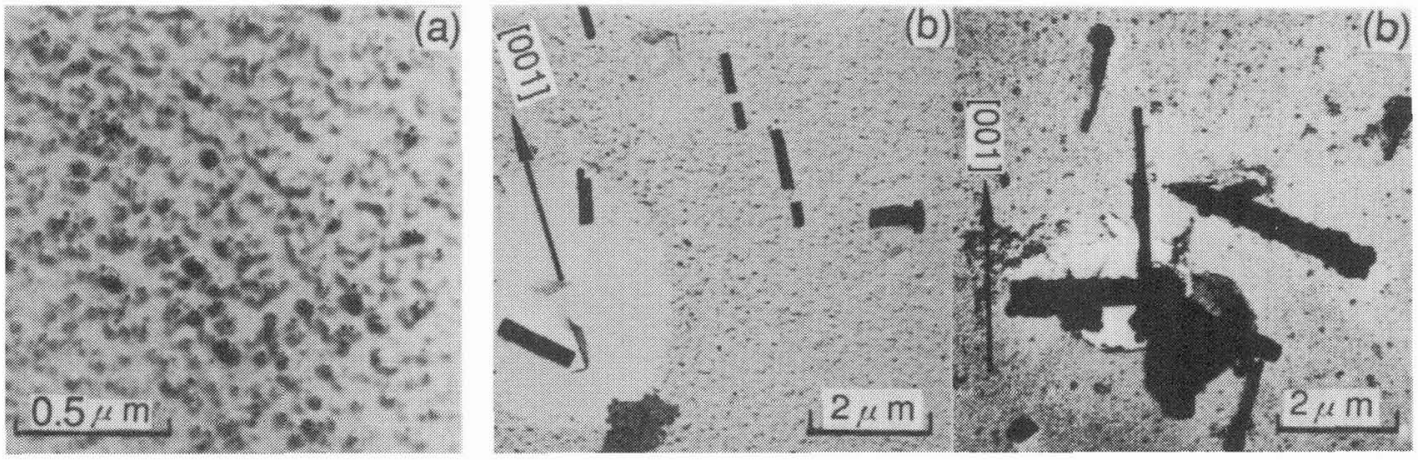

Figure 7:Precipitated AIN, (a) very fine precipitates $(0.01 \sim 0.1 \mu \mathrm{m})$ being useful for reproduction of $(011)[100][21]$,

(b) fine precipitates formed as needles ( $1 \mu \mathrm{m}$ in length) being useful for reproduction of (001)[100].

components of normal grain growth structure (PR) observed in the same oriented crystal containing AlN needles of about $1 \mu \mathrm{m}$ in length. Furthermore, a doublet $-\{113\}<110>$ and a doublet- $\{113\}<332>$-oriented main primaries disappeared. From these results, it seems that a doublet of $\{1,3,10\}<421>$-oriented secondaries develops at the expense of the above main primaries which are inhibited by very fine AlN of about $0.01 \sim 0.1 \mu \mathrm{m}$ in length.

It is important to note that (001)[100] and (001)[110]-oriented single crystals containing AIN needles of about $1 \mu \mathrm{m}$ in length reproduce the initial orientations by secondary recrystallization. This situation in the single crystal will be the same in hot band processing for formation of (001)-oriented silicon steel. Many (001)-oriented grains are observed in the centre layer of a hot band after hot cross-rolling. Some of them will behave just as a single crystal does, as described above, and grow into (001)[100] and (001)[110]oriented secondaries at the expense of the matrix main primaries. 


\section{SUMMARY}

Crosswise hot-rolled 3\%Si steel hot band containing AlN originates (001)-oriented secondaries after coldrolling and annealing. This phenomenon is possible when the ingot contains a small amount of $\mathrm{C}$ $(0.03 \sim 0.08 \%)$ and $\mathrm{Al}(0.02 \sim 0.06 \%)$, and the ingot is subjected to slabbing, second-last hot-rolling at $1250 \sim 1000^{\circ} \mathrm{C}$ and then cross hot-rolled at $1000 \sim 800^{\circ} \mathrm{C}$. The percentages of secondaries of $(001)$ [100] and (001)[110]-orientations vary in accordance with the change in the contents of C and AlN in the hot-band.

When cross cold-rolled and annealed, the (001)[100] and (001)[110]-oriented single crystals containing AlN needles of about $1 \mu \mathrm{m}$ in length reproduce the initial orientations by secondary recrystallization. It is important to note that change in size and distribution of needle-like AlN could effect the development of not only these $(001)$-oriented secondaries but also a doublet of $\{1,3,10\}<421>$-oriented secondaries. The inhibition effect caused by the special orientation relationships between AlN and parent crystal seems to be a dominant factor.

In 1965, T-Electric, M-Electric company (Japan) and AEG (Germany) requested double-oriented silicon steel with excellent orientation at a cost not over $20 \%$ higher than that of commercial single oriented silicon steel for the core material of large turbo-generator (700 1000MVA), The goal was to decrease the local heat originating in the stator core. However, the quantity requested would be small, such as $100 \mathrm{~T} / \mathrm{Y}$ in Japan. After finishing the fundamental research, the development of our process in Yawata Iron \& Steel Company took place over a period of six years from August 1961 to January 1967. The commercial hot strip was firstly annealed and cold-rolled at a reduction of 53\%, and then the cold-rolled strip cut and welded by union-melt arc method, and then cold-rolled a second time in the transverse direction at a reduction of $50 \%$. The factory tests were done eleven times, and we succeeded in getting a wide strip, 750$\mathrm{mmW} \times(0.7,1.0)$ - $\mathrm{mmt} \times \mathrm{Coil}$. The discussions in the AEG about the application of this coil for large rotating machines carried on over two years, from April 1965 to April 1967. AEG's requests were as follows, (1) this coil would be used for the core material of very large rotating machines such as over $500 \mathrm{MVA}$ especially $1,200 \mathrm{MVA}$ in order to minimize the machine, (2) possible requested quantities were estimated to be $20,000 \mathrm{~T} / \mathrm{Y}$ in all EC, 6,000T/Y in Germany and 150T/Y for AEG at that time, (3) coil size could be $750-\mathrm{mmW} \times(0.7,1.0)$-mmt $\times$ Coil with insulation film, and (4) the permissible price would be $10 \sim 15 \%$ higher, at highest $25 \%$, than the price of commercial single oriented silicon steel. Generally, core steel prices at that time were $600 \sim 800 \mathrm{DM}(10 \mathrm{DM}=900 ¥)$ for non-oriented (dynamo core), 2,000DM for single oriented (transformer). Many tests and discussions with AEG concluded that commercial production of $500 \mathrm{~T} / \mathrm{M}$ would be possible using ZS sheet mill (investment 450M¥ at that time), but the production cost would be at least 30\% higher. Finally, we had to give up this production program in August 1967.

\section{References}

[1] J. L. Walter, W. R. Hibbard, H. C. Fiedler, H. E. Grenoble, R. H. Pry and P. G. Frischmann, J.of Appl.Phys.,29(1958)363.

[2] H. J. Fischer and J. L. Walter, Trans.AIME,224(1962)1271.

[3] J. L. Walter and W. R. Hibbard, Trans.AIME,212(1958),731.

[4] F. Assmuss, K. Detert and G. Ibe, Zeit.Metall.,48(1957),341.

[5] K. Detert, Acta Met.,7(1959),589.

[6] H. E. Moebius, DP.1,009,214(1957).

[7] H. E. Moebius and F.Pawlek, Archiv. Eisenhutt.,29(1958),423,

[8] S. Taguchi and A. Sakakura, JP.35-2657(1958).

[9] S. Taguchi, A. Sakakura and T. Yasunari, U.S.P.3,163,564(1964).

[10] S. Taguchi, A. Sakakura, H. Takechi and H. Takashima, JP.38-1459(1960).

[11] S. Taguchi, A. Sakakura, H. Takechi and H. Takashima, U.S.P.3,136,666(1964).

[12] S. Taguchi, A. Sakakura, H. Takechi and H. Takashima, U.S.P.3,266,955(1966).

[13] S. Taguchi and A. Sakakura, Acta Met.,14(1966),405.

[14] A. Sakakura, J.Appl.Phys.,40(1969),1534.

[15] C. G. Dunn, Acta Met., 1(1953),163.

[16] C. G. Dunn, Acta Met.,2(1954),173.

[17] S. Taguchi and S. Sakakura, Met.Trans.AIME,2(1971),205.

[18] C. G. Dunn, U.S.P.2,700,006(1955).

[19] A. Sakakura, Proc.Int.Conf.Ultra High Purity Met.,1(1994),

[20] C. G. Dunn and P.K.Koh, Trans.AIME,206(1956),1017.

[21] A. Sakakura, Proc.Int.Conf.UHPM.,1(1994),248. 